\title{
The Role of Homeopathy as a Complementary and Alternative Medicine and its Application
}

\author{
Belinda Gousta ${ }^{{ }^{*}}$ \\ ${ }^{1}$ Medicine, Quran and Hadith Research Center, Baqiyatallah University of Medical Sciences, Tehran, Iran
}

Corresponding Author: Belinda Gousta, Medicine, Quran and Hadith Research Center, Baqiyatallah University of Medical Sciences, Tehran, Iran. Tel: +98-2181263617, E-mail: belindagousta44@gmail.com

\section{Dear Editor,}

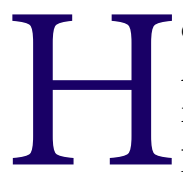

omeopathy as a Complementary and Alternative Medicine (CAM) and a holistic medicine can solve some of modern medical problems. Homeopathy, with an age of about 200 years old, first introduced by Samuel Hahnemann a German physician in 1810 and treatment for diseases with about 3,000 homeopathic remedies was addressed based on a golden principle named as "Like cure like" (similia similibus curentur). The origin of homeopathic medicines is as follows: herbal (> 80\%), salts (10\%-15\%) and animal (about 5\%). All homeopathic remedies have been recognized by the Food and Drug Administration of the United States of America in 1938 as "medicine," not a supplement or vitamin. Also, in the largest study in Switzerland in 2011, it has been approved that homeopathic remedies were effective, safe and cost-effective. To the extent that after this study, Switzerland joined the countries of Germany, England, France, Denmark and Luxembourg and provided homeopathic remedies under insurance. ${ }^{1}$

Nowadays, homeopathy is the second important medicine of world in terms of the extent of patients covered. In France, the most commonly used medicine for common colds and allergies were homeopathic remedies and about $40 \%$ of French people use these drugs for treatment. In Germany, the most commonly used treatment for Hay Fever (a seasonal sensitivity) is homeopathy. ${ }^{2}$

Results of a cohort study with 3981 patients with allergic rhinitis, headache and atopic dermatitis revealed that homeopathy could effectively reduce patients' disease severity and improve their quality of life. ${ }^{3}$

Also, homeopathy could significantly decrease pulmonary discharge in patients with Chronic Obstructive Pulmonary Diseases (COPD) who admitted in Intensive Care Unit (ICU) and mechanically ventilated. Also, patients were separated and discharged from the ventilator device faster than the control arm. ${ }^{4}$ Fortunately, homeopathic remedies efficacy on animals and herbals has been proven and these evidences discourage induction in homeopathy. For example, use of Blatta Oriental in Indian guinea pig and rat has been led to reduction of acetylcholine, histamine, eosinophil, Ig E, and mast cell in hypersensitive lungs accompanied with bronchospasm. ${ }^{5}$

In addition, Gamma interferon production rate by $\mathrm{T}$ cell has been increased up to $24 \%$ after homeopathic remedies use. Also, this evidence discourages induction in homeopathy. ${ }^{6}$

Although several studies have tested homeopathy in the treatment of many diseases; however there is still debate. These recommendations are as follows:

1- Referral of patients to homeopathic doctors to accelerate the process of treating diseases along with commonly used medicine

2- Studies on the cost-effectiveness of homeopathic remedies

3- Facilitating the entry of homeopathic medicines from foreign countries by the authorized organizations if these drugs approved to be cost-effective.

4- Encouragement and facilitation of homeopathic remedies production at an affordable price by a domestic specialist and avoiding the withdrawal of currency

5- Familiarization of medical universities' students with holistic medicine

6- Systematic review of available homeopathic remedies Randomized Controlled Trails (RCT) performed in Iran

Conflict of Interest Disclosures

None.

Copyright (C) 2017 The Author(s). This is an open-access article distributed under the terms of the Creative Commons Attribution License (http://creativecommons.org/licenses/by/4.0), which permits unrestricted use, distribution, and reproduction in any medium, provided the original work is properly cited. 


\section{References}

1. Bornhoft JM, Strabala KW, Wortman TD, Lehman AC, Oleynikov D, Farritor SM. Stereoscopic visualization and haptic technology used to create a virtual environment for remote surgery - biomed 2011. Biomed Sci Instrum. 2011;47:76-81. doi: 10.1007/978-3-642-20638-2. pmid: 21525600.

2. Reilly DT, Taylor MA, McSharry C, Aitchison T. Is homoeopathy a placebo response? Controlled trial of homoeopathic potency, with pollen in hayfever as model. Lancet. 1986;2(8512):881-6. doi: 10.1016/S01406736(86)90410-1. pmid: 2876326.

3. Witt CM, Ludtke R, Baur R, Willich SN. Homeopathic medical practice: long-term results of a cohort study with 3981 patients. BMC Public Health. 2005;5:115. doi: 10.1186/1471-2458-5-115. pmid: 16266440.
4. Frass M, Dielacher C, Linkesch M, Endler C, Muchitsch I, Schuster $\mathrm{E}$, et al. Influence of potassium dichromate on tracheal secretions in critically ill patients. Chest. 2005;127(3):936-41. doi: 10.1378/chest.127.3.936. pmid: 15764779 .

5. Chandrakant Nimgulkar C, Dattatray Patil S, Dinesh Kumar B. Anti-asthmatic and anti-anaphylactic activities of Blatta orientalis mother tincture. Homeopathy. 2011;100(3):13843. doi: 10.1016/j.homp.2010.08.006. pmid: 21784330.

6. Enbergs $\mathrm{H}$. Effects of the homeopathic preparation Engysto on interferon-gamma production by human T-lymphocytes. Immunol Invest. 2006;35(1):19-27. doi: 10.1080/08820130500496753. pmid: 16531327.

7. Mahmoudian A, Sadri G. Homeopathy satisfaction in Iran. Iran J Nurs Midwifery Res. 2014;19(5):496-502. pmid: 25400678 .

Citation: Gousta B. The role of homeopathy as a complementary and alternative medicine and its application. Int J Med Rev. 2017;4(2):62-63. doi: 10.29252/ijmr-040207. 